\title{
Individuals in the Eleusinian Mysteries: choices and actions
}

The Eleusinian Mysteries have gripped the imaginations of both ancient candidates for initiation and generations of modern scholars. They are among the most intriguing of ancient cults, as their study raises a variety of questions regarding Athenian politics, religion, philosophy, and soteriology, as well as issues surrounding the continuity of the cult from the Bronze age, through the classical period, and on into the Christian era. The Mysteries attracted individuals who participated as a matter of personal choice, offering an eschatological perspective at a time when the fashion for 'mystery' and 'oriental' cults had not yet reached the height of its popularity. Initiation by choice means that participation in this public cult, which is administered by the Athenian state, is not purely a matter of tradition, as was the case for other cults attended by citizens or demesmen. At the same time, the Eleusinian Mysteries were open to all those who wished to be initiated and they attracted a large and varied audience. The decision to participate led the initiand to take a series of preparative ritual actions and then on to the various stages of the initiation itself: the preliminary initiation, the muêsis, and, ultimately, the epopteia where the initiand becomes one who has seen. ${ }^{1}$

How should we understand the combination of the individual aspect with the collective in this cult? While the unique individual is prominent in the Mysteries, they are still, obviously, strongly characterised by socially and politically predetermined expectations. The collective aspect, on the other hand, applies here to various groupings. In what follows, we shall examine the ways in which individual and collective combine. This approach will cast light on the extent to which individuals act and the extent to which they are acted upon, the roles they are expected to play, and the space left for individual initiative. Within the framework of polis- or public cults, the Eleusinian Mysteries are indeed an exception. Not only is participation based on personal choice - itself an oddity, since attendance is still regulated by tradition -, but individual initiation promises to change one's fate in the afterlife. This focus on the individual has been seen

1 For the various stages of initiation, see Clinton 2003, 51, considering the preliminary initiation, the mustai as first-time participants, and the epoptai, the viewers, one year later. See also, with slight differences, Richardson 1974, 20; Dowden 1980; Simms 1990, 190, rejecting preliminary initiation and identifying the muêsis with the Mysteries. 
as challenging the theoretical model of polis religion, which would not address the individual as the Mysteries do, by offering an emotionally and intellectually satisfying perspective. In this respect, the relation of the Eleusinian Mysteries to other mystery cults is multi-faceted and inspiring. However, treating 'mystery cults' as a single category is liable to restrict our attempts to focus on the particular religious and social contexts which significantly differentiate cults across time and place. For instance, the categorical approach requires focusing on the notions of individual salvation and belief rather than on ritual. Both elements, moreover, are emphasised in Christianity, marking a definite break with ancient religions. ${ }^{2}$ For this reason, I will concentrate on the Eleusinian Mysteries and will limit my enquiry primarily to the context of classical Athens and will draw only secondarily on later sources. I will attempt to evaluate the space available for individual initiative, interaction with other individuals, and the integration of individuals into a new group which conveys a new religious identity that is both personal and collective.

To what extent is it possible to consider the individual in this particular cultic context? In the course of the festival, collective acts and acts involving the individual closely follow each other, as a brief summary of the calendar shows. To start with, the setting links Eleusis to the city of Athens both geographically and ritually. On 14 Boedromion, the ephebes take the hiera, the sacred things, from Eleusis and escort them to the Athenian Eleusinion. On 15 Boedromion, the sacred herald announces the festival during the prorrhêsis (proclamation). The initiates then respond to a call of the archon basileus, the highest magistrate responsible for religious affairs, and proceed to the agurmos (gathering) at the Stoa Poikile. At some point, the formula hiereia deuro (here, the animals) calls for a sacrifice. On the next day, the initiates respond to the formula halade mustai (initiates, to the sea); they march with piglets to Phaleron and bathe in the sea. 17 Boedromion is reserved for latecomers and Asclepios, honoured by a major sacrifice and a pannuchis (all-night celebration). During this time, the rest of the candidates interrupt their collective activities and rest at home. On 19 Boedromion the procession forms and leads the ephebes, priests and officials escorting the hiera (sacred things) to Eleusis. On the 20th of the month, the crowd of initiates follows Iacchus to Eleusis, likely joined at some point by the ephebes (Graf 1996, 61-4). The initiation takes place the day after, when all participants have

2 Rüpke 2011, 192; Rüpke 2013, 5. Bremmer 2014, 142-54, for previous discussions on the presumed - and denied - influence of mystery cults on Christianity regarding terminology, ritual practice, and doctrine. See Pakkanen 1996, 109-21 and 130, for the definition of individualism in Hellenistic Athens in terms of possibility of choice, of personal faith entailing a submissive attitude towards deity and of individual remaining in society. 
arrived at Eleusis. Scholars have long speculated about what was done and said during the initiation ritual. It seems certain that what took place involved single individuals in ways that I lay out below and thus indicates a focus on the individual already in the sixth century. Various aspects of this coming together in the community of initiates point to an early focus on the individual, his disposition and his fate.

\section{Personal choice and personal fate}

In contrast to most other cults, the Eleusinian Mysteries were open to various categories of people, including men and women of all ages, foreigners and slaves. According to Herodotus (8.65.4), 'whoever of the Athenians and the other Greeks wishes is initiated'. Restriction applied only to those who did not speak Greek, those who had blood on their hands, and after the Persian wars, the Persians (Isocrates, Orationes 4.157). Despite this apparent inclusivity, time and cost certainly prevented many from becoming members of this, after all, selective group.

Does free choice point here to a case of 'initiation rituals of a voluntary, personal, and secret character that aimed at a change of mind through experience of the sacred?' (Burkert 1987, 11). Most scholars have considered choice to be characteristic of the Mysteries and an important factor in shaping a personal relation with the goddesses (Burkert 1985, 285; Sourvinou-Inwood 2003, 26). We know with certainty that the experience of the rituals was perceived as changing one's fate in the afterlife. The whole setting of the festival aimed at bringing the participant to a state of receptivity to this change through alternations of dark and light, sorrow and joy. Awe that turns into joy, as Burkert acknowledges, is not about rescue or salvation but 'blessedness' and, more properly, material happiness. ${ }^{3}$ The personal character of the experience was, as we shall see later, less firmly grounded and secrecy was a concern to all initiates, as well as to the Athenian state.

3 Burkert 1987, 21. Olbos in the Homeric poems is given by the gods: de Heer 1969, 12-3; Lévêque 1982, 123. It consists in the possession of a house, wealth, family, and power. Foley 1994, 63, emphasises material happiness or success, as well as a different relation to the afterlife. We can follow Richardson 1974, 310-1 and 314, in considering it most probable that the olbios is prosperous both in his present life and after death. It is only later that the initiates appear to be living on the Islands of the Blessed or with the gods; see Graf 1974, 80-1. Olbios means more properly happy while 'blessed' has clear Christian connotations. Similarly, de Heer 1969, 4, points to the 'emotive Christian overtones' of the term 'blessed'. I therefore keep the sense of happiness in the quoted texts about the olbos of the initiates. 
To start with the Homeric hymn to Demeter, the poem describes the fate of individuals in the afterlife. While there is no reason to admit any precise correspondences between the myth reported in the Hymn and the cult practiced at Eleusis, the Hymn suggests some general ideas about the cult of the goddess that were certainly shared by at least some of the candidates. Happiness in the afterlife appears as the aim of the initiation: 'happy (olbios) is the mortal on earth who has seen these rites, but the uninitiated who has no share in them never has the same lot once dead in the dreary darkness' (480-3, transl. Foley). ${ }^{4}$ Soon after, the Hymn makes clear how this state of happiness begins in actual life: 'highly happy (meg' olbios) is the mortal on earth whom they [the goddesses] graciously favour with love. For soon they will send to the hearth of his great house Ploutos, the god giving abundance to mortals' (486-9, transl. Foley). The initiand is not only looking for an answer to the question of the afterlife, he is also looking for olbos, the wealth combined with fertility that is taken to be one of the early aims of the Mysteries. ${ }^{5}$ Demeter herself expresses the miseries and the inevitable fate of mortals when Metaneira interrupts the goddess burying the son of the queen in the fire to make him immortal. She reproaches mortals for being 'ignorant and foolish, unable to foresee destiny, the good and the bad coming on them'; they 'cannot escape death and the death spirits (ouk esth' hôs ken thanaton kai kêras aluxai)' (256-7 and 262, transl. Foley). In the Hymn, death is the prime concern of those who see the rites. Sophocles (F 837 Radt; 753 Nauck) alludes to their being awarded life after death: 'thrice happy (trisolbioi) are those among mortals who have seen these rites before going to Hades; for they alone have life there (toisde gar monois ekei zên esti), while others have all kind of misery'. In a similar formula in Pindar (F 137 Snell), seeing the rites bestows a special kind of knowledge: 'happy (olbios) is he who having seen these things has gone under the earth; he knows the end of life and the Zeusgiven beginning (oide men biou teleutan, oiden de diosdoton archan)' ${ }^{6}$ All kinds of sources allude to this privileged relation between death and initiation. Aristophanes (Peace 375) shows Trygaeus borrowing money because he needs to be initiated before he dies while Isocrates (Or. 4.28) asserts that initiation (teletê) gives more agreeable hopes about the end of life and all time (peri te tês tou

\footnotetext{
4 For Dickie 2004, 589, this is what the hierophant said to those who had just been initiated. For the viewing of the Mysteries, see Petridou 2013.

5 Bremmer 2014, 18-9, points to the fertility aspect of the Mysteries with the return of Persephone, the showing of an ear of wheat (Hippolytus, Refutatio 5.8.39) and agricultural wealth, the prominence of Ploutos and Pluto.

6 Richardson 1974, 313, suggests that the language of Pind. F 137 and Soph. F 837 is so close to that of the Hymn that imitation is likely.
} 
biou teleutês kai tou sumpantos aiônos). Heracles articulates these hopes as he presents to Dionysus the initiates in the underworld, wandering and dancing, jesting and joking in flowery meadows (Aristoph. Ran. 324-36, 342-52, 372-6, 447-59). ${ }^{7}$ They form happy choirs of men and women together clapping their hands, enjoying their existence in a breath of pipes, shining light, and myrtle groves (154-7).

All these passages show happiness and a better fate in the afterlife to be the aim of initiation. From the Hymn to Aristophanes, all sources share a common view of the afterlife the initiates will enjoy as distinguishing them from the uninitiated. This eschatological aspect of the Mysteries seems to have appealed to candidates who came to Eleusis to gain some kind of knowledge and to ensure a better fate after death.

\section{Individual initiation}

What happened during the initiation ritual remains cloaked in a shroud of secrecy. We can, however, glean some information on practical matters from inscriptions and from the blend of allusions to myth and ritual in literary and poetic works.

Starting with logistics, an inscription regulating Eleusinian matters, dated to 470-460 and found in the City Eleusinion, relates the fees necessary for initiation. Each initiate is to give an obol to an official, probably the dadouchos (torchbearer), half an obol to each of the hierophantides who had the duty to reveal the hiera along with the hierophant, and an obol at the Lesser Mysteries as well as another at the Greater Mysteries to the priestess of Demeter (IEleusis 19 C 5-14 [Clinton 2005]). ${ }^{8}$ The Eumolpidai and the Kerykes together receive money from each initiate, five obols from men and three from women (20-3). No candidate is exempted from the fees, with the exception of the child from the hearth (24-6). ${ }^{9}$ Information follows on the way to properly conduct the ritual. The Kerykes as well as the Eumolpidai are to initiate each mustês individually (Kerukas de muen dicha tos mustas hekaston); if they initiate several at once (ean de kata pleios),

7 For the relation of the Frogs to the Mysteries, see Bowie 1993, 228-38, arguing for a chorus constituted by Eleusinian initiates, olbioi continuing their cult in Hades. For the meadow as a standard piece of the Eleusinian underworld, see Graf 1974, 41-2.

8 According to Inscriptiones Graecae $\mathrm{I}^{3} 6.6-9$, the half obol is given to the hieropoios, while according to Cataldi 1981, 79, it is given to the sacred herald.

9 IEleusis 19 C 24-6. For Cataldi 1981, 79 the stress is on the age of the candidates. 
they are fined a thousand drachmas. ${ }^{10}$ The inscription then returns to financial matters.

This muêsis is the first instance within the ritual process in which initiates are individually treated. After making a free choice and participating in the public part, each of them receives the attention of an initiating official. This one-to-one ritual may have been about something the official did, said and/or showed. From what we know, some acts and formulas may have been restricted on an individual basis. At the same time, other acts addressed the whole group. For instance, the drama of the story of the goddesses, if any, was likely shown to the group as a whole, as was the marvellous vision in brilliant light. ${ }^{11}$ At some point, the initiate utters or hears other types of formulas, presumably reporting his own actions, such as the giving of the obscure password (sunthêma) reported by Clement of Alexandria: 'I fasted, I drank the potion (kukeôn), I took from the box (kistê), after working I placed back in the basket (kalathos) and from the basket in the box'. ${ }^{12}$ We do not have the slightest idea how these actions were carried out, nor at what moment in time, nor whether they formed a single sequence or extended over several days of the festival. Nor do we know if they were collective or individual actions. ${ }^{13}$ Their meaning is elusive beyond the sense they give us of participation in a common ritual that led to the happy state of the initiate.

10 IEleusis 19 C 26-30. IG I3 6 omits dicha. According to Clinton 2008, 42, pleios in 29 suggests an opposite condition should be restored in line 26 , for which dicha is appropriate, stressing the individual character of the initiation; see also Sokolowski 1959, 4. Simms 1990, 187, considers the possibility that lines 26-30 refer to the costs of initiation and not to the number of mustai. Consequently, pleios in 29 would refer to obelos instead of mustas, and hekaston in 27 to the fees rather than to individual initiation. Another possibility discussed is the restoration Kerukas de muen kath'ena and so on, where hekaston has Kerykas as subject, contradicting the prohibition of group muêsis. Clinton 2008, 42, sees hekaston modifying Kerykas as rather forced, since this would imply that each member of the Kerykes and Eumolpidai performed muêsis. 'Each', after Clinton, most naturally pertains to the mustai, each of whom takes part in ritual. Clinton remarks that the ritual had certainly been conducted for groups for convenience, hence the penalty.

11 IEleusis 637 (215 CE); Plutarch, Mor. 81e; Plut. F 178. This leads Parker 2015, 72, to consider the collective character of initiation as increasing the intensity of the experience. For the relation between the representation of death and ritual, see Graf 1974, 126-38. The question has fascinated philosophers and later authors who have related a drama of Demeter's sufferings to the representation of the initiates in the afterlife.

12 Clem. Al. Protr. 2.21.2. See also the tokens (sumbola) reported in 2.15.3: 'I ate from a drum (tumpanon), I drank from a cymbal, I carried the kernos, I went into the chamber'.

13 According to Bremmer 2014, 3, these acts would not have been part of the Mysteries because there would not have been enough time for some thousands of initiates to perform them. He thus relegates them to the Lesser Mysteries or to another time. 


\section{Initiates as a group}

If the previous acts refer to the initiate primarily as an individual, how do the initiates participating in the ritual as a group relate to each other? The ritual identity of the initiate connects citizens, non-citizens, foreigners, young and old, men and women. The bonds forged between them are situational, regardless of civic identity or territorial claims. Nor do they connect the whole polis population. They are a collective for and during the festival. The question is then what happens after the festival. Is there any indication of Eleusinian initiates forming a group or a community?

The initiates act as a group during the public parts of the festival, and certainly in the more obscure parts of the festival that took place within the sanctuary as well. When we refer to a group we essentially talk about a large crowd, as the Persians' reaction indicates. Watching the procession from afar just before the battle of Salamis in 480, they heard the song of Iacchus and saw dust coming from Eleusis as if there were thirty thousand people. ${ }^{14}$

The procession formed an impressive spectacle. The initiates wore festive clothes, were crowned with myrtle, and held a branch called bacchos. The splendour of the procession was important enough to make Alcibiades a favourite among the Athenians because he had it restored during the Peloponnesian war. He conducted the priests, the mustai and the mustagôgoi in order (en kosmôi) and silence (meta siôpês), an awesome (semnon) spectacle for his fellow citizens who witnessed his valour and hailed him as hierophant and mystagogue. ${ }^{15}$

According to the Athenians, this cult promises that 'the greatest good among men is acquaintance with one another and trustworthiness' (IG $\mathrm{II}^{2} 1134.20-1$, 117/6, transl. Clinton 1999, 98). There is evidence that those undergoing initiation together become brothers (adelphoi). ${ }^{16}$ We may understand this relationship from co-initiation by Dion's misfortune. This disciple of Plato was initiated and hence was attached to two brothers from Athens, Callipus and Philostratus. Their friendship came from companionship and sharing in religion, initiation and epopteia.

14 Hdt. 8.65.1; Plut. Themistocles 15. Could it be the multitude (pletthos) of the 'law concerning the Mysteries' IEleusis 138 Bf 6 (367/6-348/7)? For Clinton 1980, 273, and Clinton 2008, 117, the increased popularity of the Mysteries motivated this 'new code', the 'most extensive set of regulations we possess from antiquity concerning this cult'. The document's value as a code is refuted by Scafuro 2010, 39.

15 Plut. Alcibiades 34.3-5. Simms 1990, 193, considers this appearance of the mystagogue as an anachronism projected back to the fifth century.

16 Sopatros 8.123.26-8: an daidouchian theasômai kai schêma ti peri tou adelphou gignomenon. See Burkert 1987, 45 and n. 77. According to Parker 2005, 361, n. 152, Sopatros' reading is probably wrong. 
Arriving in Sicily, they found out that Dion was charged with plotting a tyranny and killed him. This shameful (aischron) and disrespectful (anosion) act from brother to brother brought shame on the whole city. According to Plutarch, the outrage of the goddess was as great as if her mustês were slain by his mystagogue, implying that Callipus had initiated Dion (Plato, Letters 7.333d-334b; Plut. Dion 56.4. Bremmer 2014, 3).

This episode illustrates an ideal relationship that is disrespected. We may doubt, however, that there existed a larger brotherhood comprising all initiates from different social classes and milieus. It is similarly doubtful that the Mysteries ritually reinforced group solidarity beyond the context of the ritual (Sourvinou-Inwood 1990, 305). The group of the initiates has indeed been thought to form a community, based on their collective religious identity and experience. ${ }^{17}$ However, the status of initiate does not entail an exclusive individual awareness of belonging nor self-description as a member when the ritual is over. ${ }^{18}$

After the Mysteries are over, there is no more unified group. ${ }^{19}$ The initiates' return to their usual mundane environment somehow dissolves the ties that bound them together during the festival. They are not required to return to Eleusis unless they seek to achieve a higher degree of initiation. From their departure from Eleusis onwards, except for the initiates in court who isolate themselves from the uninitiated in order to avoid revealing the secrets of the ceremony if the case regards the Mysteries, ${ }^{20}$ we know of no other collective activities. Initiates occasionally come together, as in the case of the mimicking of the Mysteries by Alcibiades and his friends, but we never hear of a formal association of initiates.

17 Burkert 1998, 377, considers a new community. If community there is, it is clearly not one formed around one religion or a civic status (see Graf 2003, 9) and it would also count among its members mythical initiates, such as Dionysus Mustês (Pausanias 8.54.5) and Heracles (Diodorus of Sicily 4.14.3; Plut. Theseus 30.5).

18 Rüpke 2016, 4, defines a group as sharing concepts and a collective religious identity, considering in all cases these identities to be differentiated and dynamic.

19 As Burkert 1987, 43, remarks, there is no credo after this experience, nor is the group united by faith. See Bremmer 2014, 138, on the lack of special groups of Eleusinian initiates in Attica.

20 Andocides, On the Mysteries (I) 12.28-9 and 31. See Sourvinou-Inwood 1997, 145. According to Pollux 8.124 and 141, the jurors are chosen in this case from the epoptai and the court is cordoned off by a rope. As to the jurors, they are elected by lot from among those over thirty and not in debt to the treasury: Aristot. Ath. Pol. 63.1 and 3. 


\section{From personal choice to religious individualisation}

Personal choice seems to be part of the individualisation process. We need to keep in mind, however, that the individual is entangled with the collective. While personal and free choice is a requisite for initiation, future initiands are drawn in some way to the Mysteries by acquaintances who are already initiated. ${ }^{21}$ Muêsis requires a mystagogue, a guide, time devoted to preparatory learning and paradosis, transmission of knowledge. ${ }^{22}$ The mystagogue leads the participant to the completion and success of his initiation (Hesychius, s.v. mustagôgos), as the hierophant does later in the process. They both have, at some point, a one-to-one relationship with each initiate in order, presumably, to tell or show him what is coming.

Regarding the significance of knowledge in the initiation process, Aristotle (F 15 Ross; Synesius, Dion 8.48.42-4) states that the initiates should not learn anything but, rather, experience or suffer in order to be put in a certain disposition (ou mathein ti dein alla pathein kai diatethênai) and to become suitable in ways that are not to be articulated (kai hê epitêdeiotês de alogos). ${ }^{23}$ Even though Aristotle has been largely followed to the letter and learning considered as opposed

21 Bremmer 2014, 3, n. 3, for the sources. And. Myst. (1) 132, alludes to his having initiated a Delphian and another friends of his from outside Attica, and the orator Lysias had promised to initiate his mistress Metaneira (Demosthenes, Against Neaira [59] 21). For Simms 1990, 191, this would mean merely taking care of the expenses.

22 The mystagogue's role clearly relates to teaching: Posidonius F 368 (didaskalou kai mustagôgou); Plut. Mor. 795e (didaskôn kai mustagôgôn); or simple assistance: Plut. Mor. 765a; Sopatros 8.123.22-3; Menander F 714 (Sandbach; Plut. De tranquillitate animi 474 B 6): mustagôgos tou biou agathos. Instruction relates, for many later authors, especially to the Lesser Mysteries. For Clem. Al. Strom. 5.11.71, the Lesser Mysteries are about teaching and preparation for what is coming (didaskalias tina hupothesin echonta kai proparaskeuês tôn mellontôn), and the Great Mysteries are about everything, where one does not learn (ou manthanein) but sees and ponders nature and things (epopteuein de kai perinoein tên te phusin kai ta pragmata); see Riedweg 1987, 5-14. For Simms 1990, 191-5, the mystagogues conducted the indoctrination of mustai early in the Mysteries and he links them with the Eumolpidai and the Kerykes, recalling IEleusis 138 A 27 (infra note 35), separating the muêsis and the leading of the mustês to an Eumolpid or a Keryx, and equating muêsis and mustagôgia, also noting the relatively late appearance of the term, especially after $100 \mathrm{CE}$.

23 Or as Bernabé 2016, 34, translates: 'those who become initiated should not learn anything, but rather experiment and change their mentalities, this is, achieve due preparation'. He translates pathein as 'to experience', 'to receive an external stimulus without implying any activity from the subject'. For Albinus 2000, 156, n. 6, Aristotle's statement could have been polemic. 
to experiencing, pathein is closely related to learning through experience. ${ }^{24}$ If we accept that knowledge was somehow related to muêsis, it may have been transmitted in advance. The experience of the Mysteries is guided and somehow instructed by the various officials. Before the muêsis, some kind of interpretation (exêgêsis) is provided to the mustai (IEleusis 250.27, second-first century), possibly by the mystagogues. ${ }^{25}$ An individual pre-initiation was apparently administered at some point by a member of the Eumolpidai or the Kerykes. This seems to have been a preparation through information provided by a mystagogue or the officials. This is clear in the story of two uninitiated Acarnanian youths who entered the sanctuary unwittingly and were given away by questions revealing their ignorance of Eleusinian matters. ${ }^{26}$ Part of the preparation may have been hearing the logos narrating Demeter's kindness towards the Athenians, which was only allowed to be heard by initiates (Isoc. Or. 4.28). In addition to certain types of knowledge gained before the initiation, a different kind of knowledge is thought of as resulting from the initiation itself. Pindar (F 137) for instance claims that the initiated gained insight (oiden) into the end of life and the Zeus-given beginning.

Given the centrality of gaining some kind of knowledge or insight through the process, the question is how this knowledge affects individuals. Pre-initiation knowledge may indeed prepare the candidates but, at the same time, it marks them out from the uninitiated. ${ }^{27}$ Marking out is not yet individualising. At the other end of the process, the final experience is individual, as is the mysteric

24 Aeschylus, Agamemnon 177, reports the very wish of Zeus that 'wisdom comes from suffering': ton pathei mathos. Talking about mysteries in general, Plut. F 178, states that knowledge comes to the soul at the moment of death, when it undergoes an experience similar to that of the participants in the great initiations (tote de paschei pathos oion oi teletais megalais katorgiazomenoi). As Bernabé 2016, 37, remarks, this knowledge comes from experience and not from being told.

25 According to Clinton 2008b, 33, this is a period set aside for the muêsis, a few weeks before the Greater and Lesser Mysteries. The quoted passage follows that concerned with what happens to the mystagogues if they do not march with the mustai in the procession (1. 26) and could be related. IEleusis 138 A 38-40, also mentions the exêgêtai that start their work on the Athenians and on foreigners on Metageitnion 1, well before the muêsis. Larson 2016, 273-6, assumes transmission of knowledge about eschatological promises, the basics of Eleusinian theology, cult terminology, hieroi logoi tied to the landscape of the sanctuary, the significance of a password and rules of secrecy, assuming that there was a large amount to be learned by each mustês.

26 Livy 31.14.7-8. The youths were eventually put to death. See Parker 2005, 346; Larson 2016, 274.

27 Parker 2005, 345. Bernabé 2016, 37, points to the use of oiden, the perfect form of the verb 'to see' expressing the present result of a past action: whoever has seen the mysteries now retains these visions. Petridou 2015, 254-6, stresses the relationship between the vision of the rites and knowledge. 
sacrifice of piglets offered on behalf of each initiand, contrary to collective rituals where the animal was brought on behalf of all (Schol. Aristoph. Ach. 747). Even so, the initiate does not achieve anything on his own, guided as he is by acquaintances, a mystagogue, and then by the hierophant. He achieves his initiation only through mediators and through the ritual itself. One might then argue that while it involves marking out the participant, the experience is not necessarily one of strict individualisation. The effect of the initiation, moreover, is the same for all candidates.

In the frame of this barely sketched individualisation we can include a personal moral disposition which appears to be necessary. Aristophanes (Ran. 455-9) counts among the happy ones who 'enjoy the sun and the light' those who have been initiated and who behaved properly (hosoi memuêmeth' eusebê te diêgomen tropon) to foreigners and ordinary people. In the same play (Ran. 354-7) he uses a formula resembling the prorrhêsis stating that one cannot join the choirs of the initiates who 'is not pure in thought (hostis... gnômên mê kathareuei), has neither known nor danced in the rites of the noble Muses and has not been initiated into the Bacchic rites of the tongue of Cratinus the bull-eater' ${ }^{28}$ Purity will be more significant in later periods and in other religious contexts, more particularly orphism, yet the moral distinction drawn between the happy ones, on the one hand, and the uninitiated and those who have transgressed rules, on the other, is already present in the classical period (Petrovic, Petrovic 2016, 263). The dominant opinion is that the just and pious are rewarded (Rudhardt 1992, 119). Transgression and non-initiation are put on the same level and entail punishment, inflicted on the uninitiated dead through encounters with monsters and laying in mud. ${ }^{29}$ This relates the afterlife to moral values and the distinction certainly reflects some of the shared understandings of the time. ${ }^{30}$ Morality and purity ascertained by initiation

28 As Bowie 1993, 239, and Petrovic and Petrovic 2016, 243-4, remark, this echoes the Eleusinian prorrhêsis. See also Burkert 1985, 289; Dickie 2004, 588 and Schol. Aristoph. Ran. 369.

29 Soph. F 837 Radt (753 Nauck). Aristoph. Ran. 144-51, describes ten thousand snakes and terrible wild beasts, dung where whoever wronged his guest, or screwed a boy and took back a pay, or thrashed his mother, or smacked his father's jaw, or swore a perjured oath lie. Paus. 10.31.9, describes the leschê of Polygnotus at Delphi and the fate of two uninitiated women, carrying water in broken jugs. In Pl. Grg. 493b, they carry water into a leaky jar with a sieve. For the punishment of the uninitiated, see Fabiano 2010.

30 See Graf 1974, 86, on the moral aspect of this assertion, combined with Pl. Phd. 69c, contrasting the uninitiated (amuetos kai atelestos) lying in the mire with the purified and initiated (kekatharmenos te kai tetelesmenos) living among the gods; Plut. F 178, presents the initiates along with the pious and the pure (sunestin hosiois kai katharois andrasi). See also Dickie 2004, 585-6; Parker 2005, 361. 
could be used for further purposes. For instance, Demetrius hastily undergoes all stages of initiation at once for his own political purposes. This is his way of displaying a superior morality in contrast to his political opponents and of claiming purity from blood after the murders in the dynasty of Alexander. ${ }^{31}$ Philosophers, on the other hand, often use the Mysteries to confirm their theoretical positions or to add a religious dimension to their exercises (Burkert 1987, 85; Waldner 2013). Finally, administrators of the Eleusinian Mysteries focus on the aspect of ritual that suffices for the initiation (Larson 2016, 270). The moral focus thus shifts or is nearly absent, depending on the perspective and the purpose of the sources.

The varying natures and contexts of our sources have sometimes been neglected and this has led to the creation of a stereotype of spirituality that tends to be contrasted with the usual ritual display of the polis that would prevail over belief (Petrovic, Petrovic 2016, 2). Burkert points out some of the problems of spirituality and sees the ancient mysteries as a personal but not necessarily a spiritual form of religion (Burkert 1987, 87). But even the personal aspect of such a form can be questioned, since the personal needs of the candidate for initiation are hardly distinguished from the shared religious concerns which render them almost communal and even political (Kindt 2015, 39).

We may also wonder what is meant by spiritual. ${ }^{32}$ If it is a concern for the fate of the psuchê, we only have indirect evidence that the Eleusinian Mysteries were 'spiritual'. ${ }^{33}$ Yet the picture of the initiates in the underworld described in the makarismos of the Homeric hymn is closer to the ideal existence of the orphic utopia, as Bernabé puts it. It stands in contrast to the depiction of the feeble ghosts in the Od.10.560, when Circe gives Ulysses directions to the house of Hades where the dead, the psuchai, end up. There, Ulysses is to invoke the dead and to sacrifice to the fleeting heads. These are a famous race, the shadows of the dead. ${ }^{34}$ Their gloomy description in the epic not only contrasts with the happy fate of the olbioi in the Homeric hymn but also brings out the coexistence of these two contrasting understandings of the afterlife, despite the generally admitted change in attitude towards the afterlife in the archaic period (Sourvinou-Inwood 1997, 139-40).

31 Plut. Demetrius 26.2. Kuhn 2006, 269, also stresses the demonstration of Demetrius' complete integration into Greek culture.

32 Regarding Burkert's assertion, see Albinus 2000, 198.

33 Orphism by contrast was spiritual in stating the immortality of the soul; see Bernabé 2012, 13-4.

34 Od. 10.521, 536; 527; 530, with their repetition in Od. 11.29-65. For the psuchê in Homer, see Bremmer 1983, 15-7; Sourvinou-Inwood 1995, 56-8. 
One last aspect of the Mysteries that connects the individual and the collective is secrecy. Secrecy is implied in the sources from the Homeric hymn (478-9, transl. Foley) onwards: the rites are 'not to be transgressed, nor pried into, nor divulged' (ta t'ou pôs esti pareximen oute puthesthai, out' acheein). The Hymn (479) stresses the reason for the secrecy, that 'great reverence of the gods restrains utterance' (mega gar ti theôn sebas ischanei audên). For Strabo (10.3.9) things are slightly different: 'the secrecy with which the sacred rites are concealed induces reverence for the divine (semnopoiei to theion), since it imitates the nature of the divine, which is to avoid being perceived by our human senses'. A growing stress on the secrecy of the cult appears in our sources from the Imperial period, with Pausanias refraining from describing the Athenian Eleusinion and the sanctuary of Eleusis (Paus. 1.14.3 and 1.38.7), and the name of the hierophant being included amongst the secret matters (Clinton 1974, 9).

The initiate is to keep the secret of the Mysteries but this is, at the same time, a secret of the whole society (Bremmer 1995, 70; Burkert 1998, 378). When the collective secret was at times divulged, trials took place and the issue was handled by the Athenian state. When accused, Aeschylus seemed unaware of what he had divulged and claimed to be uninitiated (Aristot. Eth. Nic. 1111a; Clem. Al. Strom. 2.14.60; TGrF 3, T 93 Radt). He was eventually acquitted. Diagoras of Melos was accused of mimicking the Mysteries (Lysias, Against Andocides 17; Melanthios, FGrHist 326 F 4; Aristoph. Av. 1073-4), as was Alcibiades at the time of the Sicilian expedition. Both were condemned. In all cases of impiety for divulging the cult secrets, the city made the final decision on the offence and punished the offenders, cultivating reverence for the two goddesses and their Mysteries (Gagné 2009, 220-2).

There emerges a quite intricate picture of the initiation process. Aspects that stand out are the acquisition of different types of knowledge, elements of moral disposition, and secrecy. In our sources, however, we find that the different aspects are variously highlighted. And as a result, individual and group, personal choice and collective or civic affairs, merge in a range of ways. The complexity of the evidence and how the individual and group merge is also brought out by the initiatives of officials.

\section{Eleusinian officials and the Athenian city}

The place left for the initiatives of Eleusinian officials is suggestive of the significance of the cult in the Athenian city. The main officials originated from two Eleusinian families, the Eumolpidai and the Kerykes, which were associated with 
performing initiations. ${ }^{35}$ The Eumolpidai provided the hierophant, the official who showed the sacred things during the culminating point of the ceremony. The dadouchos and the sacred herald were provided by the Kerykes. In both cases, their authority came partly from the knowledge that was passed down through the families for generations. ${ }^{36}$ However, the supervision of the festival was the task of the annually elected Athenian basileus, along with the epimeletai or curators elected by the People, two from the Athenians, one from the Eumolpidai and another one from the Kerykes, as stated in a 'law concerning the Mysteries' (IEleusis 138 A 30-1, 367/6-348/7; Aristot. Ath. Pol. 57.1).

Most officials of the Mysteries acted as a group and appear to have had little eminence as individuals. A few exceptional cases involve the attitude and actions of officials towards questions of impiety, mostly taken for political reasons. The hierophant Eurymedon, for instance, is known for bringing Aristotle to trial, accusing him of impiety for having composed a hymn in honour of Hermias. ${ }^{37}$ This prosecution, however, had nothing to do with Eurymedon's position at Eleusis; he merely acted as a citizen (Gagné 2009, 222). There are also instances in which officials ordered to act as a group denied the authority of the request. Thus, in 415, the priestess Theano refused to curse Alcibiades despite a decree stating that 'all priests and priestesses' were to curse him. The reason she gave was that she was a praying and not a cursing priestess (Plut. Alcibiades 22.5). When the People eventually decreed the return of Alcibiades in 407, the hierophant Theodoros refused to revoke his curse. He claimed he had invoked no evil upon one who did no wrong to the city, so that his curse was void. ${ }^{38}$ In so saying, Theodoros subtly acknowledged the authority of the city while at the same time defying it. He tried, and succeeded, to differentiate his own actions from those of the priestly board. Later, the dadouchos Pythodoros refused to initiate Demetrius Poliorcetes when he asked that the calendar be modified in order to allow him to undergo all the stages of initiation at once. Pythodoros' refusal had no effect,

35 It is illegal indeed, according to IEleusis 138 A 27-9, for one knowing that he is not a member of the Eumolpidai or the Kerykes to perform the muêsis. It is also illegal to introduce a candidate to initiation to someone who is not a member of these families.

36 This factor is clearly at play for the dadouchos Themistocles in IEleusis 300.63-5.

37 Diogenes Laertius, Aristotle (5) 5. Before that, Diogenes Laertius reports another story in which Aristotle fell in love with a concubine of Hermias and sacrificed to her as the Athenians did to Demeter (3-4), but this is not included in his charges. Similarly, the hierophant Eurycleides accused the philosopher Theodorus of joking about the Mysteries. He was eventually saved by Demetrius of Phaleron or condemned to drink hemlock: Diog. Laert. Aristippus (2) 8.101; Athenaeus 15.696a.

38 Plut. Alcibiades 33.3. As Burkert 1995, 205, remarks, this is logic encroaching on ritual. 
even though he had authority over the ritual. ${ }^{39}$ Other officials at times opposed Eleusinian authority in order to defend their own rights and were successful. An anonymous priestess in the fourth century opposed the hierophant Archias over her rights and he was convicted of impiety by the Athenian court for having performed a sacrifice contrary to the ancestral tradition (Dem. Or. 59.116-7).

Many dadouchoi were also distinguished and politically active individuals. Kallias the second was part of the embassy that negotiated the truce with Artaxerxes in 449/8 and he also negotiated the truce with Sparta in 446/5. ${ }^{40}$ Kallias the third was general in 391/90 during the Corinthian war. Acting as envoy to Sparta, he gave a famous speech reporting the civilising mission of Triptolemos among the Peloponnesians and the tradition that he revealed the Mysteries first to Heracles and the Dioscouroi, the founder and the citizens of the Spartans (Xenophon, Hell. 6.3.2-6). He was also involved in dubious affairs, such as the accusation of Cephisius against Andocides in 400 for placing a suppliant's bough on the altar of the Eleusinion during the Mysteries. ${ }^{41}$

The honours accorded to Eleusinian officials attest to the prestige of their families and their involvement in the political life of the Athenians. The focus on their public life contrasts with the anonymous crowds of the initiates, until the Roman period when most prominent politicians would travel to Eleusis to undergo initiation. ${ }^{42}$ Cult officials acted, then, as eminent citizens and therefore as individuals in a way that is entirely different to that of the initiates. They were entitled to oppose each other and, at times, even the decisions of Athenian politicians. Praised for their dedication to the cult, they were, at the same time, carefully pursuing their own agendas.

\section{The initiates}

From our evidence, it is very hard to identify who participated in the Mysteries. The question shifts to whether participants act and appear as individuals or as a

39 Plut. Demetrius 26.1. Kuhn 2006, 267, illustrates by this case the complexity of the issue of ritual authority and of the meaning and power of ritual knowledge in practice.

40 Schol. Aristoph. Nub. 64. On the legendary wealth of Kallias, see Plut. Aristides 5 and 25. For the personage and his family, which dominated this office during this period, see Clinton 1974, 47-8.

41 And. Myst. 112-7. Politically active officials are far more common during the Roman period. See Clinton 1974, 68, for dadouchoi holding distinguished offices.

42 Clinton 1989b, 1500, dates the interest of Romans in the Mysteries to Cicero's time; see Clinton 1997,163 , on the steady stream of them travelling to Eleusis. For the prosperity of the sanctuary between the Hadrianic and Severan periods, see Lippolis 2013. 
group. A special official seen as representing the Athenians is also worth considering in this context.

Regarding the social context of participation in the Mysteries, the regulation from 470-460 addressing all those who wished to use the sanctuary set a truce for the protection of the visitors travelling to Eleusis (IEleusis $19 \mathrm{~B}$ and later IEleusis 138 B 14-7. See Clinton 1994, 162-3). All were welcome although not all came. The picture of the chanting crowds heading to Eleusis points to mass initiation and, as a norm, Athenians who could afford it would be initiated (Parker 2005, 343; Bremmer 2014, 4). Much later, at least, being initiated was an assurance of a degree of popularity, as is shown by Lucian's (Demonax 11) account of the unpopular character of the Cynic Demonax: alone of all he refused to be initiated. This means that most people wished at least to go to Eleusis. Notwithstanding the cost of the Mysteries, the social pressure to take part alongside everyone else must have been strong. Other groups of initiates are identified as the ephebes lifting the oxen for the sacrifice and the slaves who worked in the sanctuary $\left(I G \mathrm{II}^{2}\right.$ 1028.10-1 [100/99]; IEleusis 159.24).

When we turn to politicians, it appears that involvement in the Mysteries increases their popularity and at the same time increases the magnificence of the festival for all to see. This is exactly what Alcibiades did by restoring the procession during the Peloponnesian war. The magnificence contributed in turn to the attraction of more initiates and of more prestigious participants. This dynamic renders the personal choice of those undergoing the ritual for political reasons a tricky notion. Such a choice is socially prescribed by the identity a powerful individual adopts, constructed from several civic as well as religious titles. ${ }^{43}$ For some, participation in the Mysteries was part of their public image. For others, the choice was made for what we understand as an individualistic goal regarding olbos and the afterlife. Their personal development is suggested by the chanted fate that awaits them in the underworld.

Among the initiates, we have some evidence - albeit very difficult to interpret - for the so-called child initiated from the hearth. Through this special initiate, a rather sophisticated way of reconciling the character of the Mysteries as a central polis cult with their limited accessibility through individual initiation

43 This is particularly clear in the case of the Roman emperors, for whom the festival becomes a must at a time when Eleusis became a centre for imperial cult; see Clinton 1989b, 1503-9; Clinton 1997, 163-73. For Hadrian, see Clinton 1989, 56-7, and Clinton 1989b, 1516-9. Also, Clinton 1999, 94-7, on the evidence for Augustus, Tiberius and Claudius or Nero. In this context, the formalities of the initiation through the Lesser Mysteries in Anthesterion, the Great Mysteries in Boedromion and epopteia a year later may have been simplified for Roman initiates as they had occasionally been for a few politicians wishing to undergo all stages at once. 
has been suggested. The pais aph'hestias muetheis, selected by lot among the Athenians, is often seen as symbolically representing the whole Athenian polis (Harpocr. s.v. ... ho aph'hestias muoumenos Athênaios ên pantôs). ${ }^{44}$ If this interpretation is valid, the representative character of this participant may minimise the significance of individual choice. Porphyry (Abst. 4.5) compares those who sacrifice to the gods on behalf of the polis with the child from the hearth who implores the gods in the place of all the initiates (anti pantôn tôn muoumenôn). The child therefore had the role of offering prayers and sacrifices on behalf of the initiates and, possibly, on behalf of the city as well, according to Kevin Clinton. ${ }^{45}$ The child was, then, certainly important to the city that paid for his/her initiation fees. ${ }^{46}$ The title has been variously understood as pointing to the city, as symbolised by the public hearth, or to the first and primordial initiate (Clinton 1974, 99). Besides Porphyry, however, there is no clear evidence on this initiate's being in any way representative of the city. The evidence shows these paides to be members of well-to-do families and wealth appears to have been a criterion for a candidate for the position, as much as tradition or family choice. It becomes apparent then that choice can hardly be thought of as individual in this case. Just like other officials, the child bestowed fame as much as he received it from his family. ${ }^{47}$ Notwithstanding this realistic description of the perfect candidate, we hardly have any evidence on the actual function of the child. Whether the city was indeed represented is hard to assess. Porphyry's comparison indicates that the child represented all the initiates rather than the city. In all cases, the interpretation of representativeness does not imply 'that all members of ancient societies were in principle equally religious' (Rüpke 2011, 192; 2013, 3), as the polis religion theoretical model suggests. Individual choice draws a line between the initiates and the rest of the citizens and there does not seem to be a way to integrate into the first category other than through the ritual of initiation.

44 Sourvinou-Inwood 1997, 151. Albinus 2000, 183-4, n. 44, points to a possible symbolic connection between this initiation 'from the hearth' and Demeter's nursing of Demophon 'in' the hearth. The child appears thus to be a representative of the people, as was Demophon in the myth. For Bremmer 1994, 85, the presence of the child fits with the origins of the cult in the archaic puberty rites of a genos.

45 Clinton 1974, 99, points to the high respect accorded to them, attested by a great number of honorific dedications of the Hellenistic and Roman periods issued by the Areopagus, the Council and the People.

46 IEleusis 19 C 24-6, is of highly uncertain meaning, as is IEleusis $138 \mathrm{Bd}$ 5; Anecd. Bekk. 204. 47 Clinton 1974, 100-1 and 108-13, lists between the last quarter of the second century BCE and the middle of the third century CE future ephebes, sons and grandsons of priests and daughters and granddaughters of priestesses, kanêphoroi and arrêphoroi, exêgêtai of the Eumolpidai and members of the Kerykes, archons, and other members of distinguished Athenian families. 
Political and social considerations with regard to initiation do not alter the aim of the ritual and the olbos gained through it that is praised in the Homeric hymn. Eschatological concerns are already visible in the Hymn. Even so, scholars have only admitted eschatology as part of the Mysteries in later periods. According to this approach, the Mysteries originated as a civic cult without eschatological concerns. ${ }^{48}$ Notwithstanding the original nature of the cult, which is beyond our understanding, it was certainly a civic cult since it was administered by the Athenians. At the same time, the promise of a happy afterlife in the cult of Demeter appears as early as the Hymn. This evidence indicates that the premises of a civic cult and eschatological concerns could certainly be combined. Moreover, eschatological concerns appear to have been significant in a cult that was largely controlled by the Athenian city well before the classical period. Different theoretical models, however, raise questions about a potential contradiction, as I discuss below.

\section{Theoretical models for the Mysteries}

The Mysteries have been seen as 'a remarkable anomaly in the panorama of civic religious practice of archaic Greece', because they were state-sponsored, on the one hand, but 'secret' and oriented toward winning a better fate for individual initiates, on the other hand (Stehle 2007, 165). Various things the initiates did during the festival, such as wandering, searching, mourning, or joking, imitated the actions of the goddess, bringing the participants into a relationship of intimacy with Demeter. ${ }^{49}$ On this view, the experience of the Mysteries was one that the 'standard sacrificial ritual' did not provide.

Despite the difficulties involved in defining what 'standard sacrificial ritual' might be, the Eleusinian Mysteries are part of what Sourvinou-Inwood has called the Athenian polis religion, which takes the individual as its basic cultic unit

48 Bremmer 1995, 72; Parker 2005, 343. Bremmer 2014, 18, claims that the emic explanations of the reverence for the divine forbidding the Mysteries to be performed outside their proper ritual context contained no esoteric wisdom. Sourvinou-Inwood 1997, 152, argues for a shift from a polis cult of agricultural nature to an initiatory soteriological cult. This shift has also been claimed by comparative anthropologists. See Richardson 1974, 12-8, for former theories about the origins, the development and the significance of the Mysteries, namely the Corn-mother and the Maiden, and the shift from the agricultural paradigm to the personal, or eschatological, development towards a happy existence after death.

49 Stehle 2007, 176-7. It is, however, going too far considering identification with or presence of the goddess in that, eventually, the participants become Demeter in wandering and then are with Demeter in the Telesterion, as the author claims. 
(Sourvinou-Inwood 1988, 264). Sourvinou-Inwood claims that individual rituals were not abnormal nor different from group rituals and there was, thus, no rupture between the usual polis cults and those involving individual initiation or choice (Sourvinou-Inwood 1988, 266). Individual initiation was, however, certainly unique and did not function in the same way as did the collective rituals we know of. Significantly, the Mysteries do not appear as an alternative to mainstream practices but merely as an additional option (Waldner 2013, 218). Yet the model of polis religion has much to offer for those seeking to understand the Mysteries. ${ }^{50}$ Taking some of these nuances into account and combining them with aspects of the individualisation concept (Otto 2017), we can see that the Mysteries stood at the intersection of both models. ${ }^{51}$ As Walter Burkert stressed some years ago, even though the mysteries - without considering those of Eleusis in particular - were characterised by secrecy and individual implication, they were not private and nor were they in opposition to the polis.

It is significant that the polis itself seems to have encompassed and legitimated all the religious activities of its members, including activities related to eschatological concerns (Sourvinou-Inwood 1988, 264-6; 1990, 297-300; 1997, 151). Not only were the Mysteries controlled by the polis but they also contributed, just as did other civic cults, to the defining of the polis' religious identity, with the Eleusinian sanctuary serving as a symbol of civic identity and unity (de Polignac 2009, 430). The Athenians used Eleusis to reinforce their international prestige and influence in the Greek world, as well as to provide a source of income. ${ }^{52}$ The contribution of the Mysteries to the religious identity of the city is not restricted, however, to the region of Athens or even to its sphere of political influence. The kind of religious identity that it created encompassed initiates who came from all over the Greek world and beyond. Such a collective identity incorporates individual choice in various ways. Initiation can, therefore, be seen as a process

50 Kindt 2009, 15, considers the relation between polis and religion to be far more complex than this model allows. Eidinow 2011, 11, based on more or less the same critique, solves the issue of 'loose ends' left by this model as marginal by invoking the social networks, or sets of nodes representing individuals or groups linked by ties representing relationships, not all of which occur in polis-centred ritual activity.

51 Sourvinou-Inwwod 1995, 38, already believed that the Mysteries and other movements can only be thought of as marginal if one ignores the intimate intertwining of the Eleusinian Mysteries with Athenian polis religion.

52 Isoc. Or. 4.28. Clinton 1994, 161. For the rhetorical manipulation and political exploitation of Demeter's xenismos in Athens, see Petridou 2015, 305-9. The income is secured by the practice of the aparchai known by the decree $I G \mathrm{I}^{3} 78$ a 4-8, 24-6 (IEleusis 28, 440-35), urging during the Mysteries that all cities should offer aparchai 'according to the ancestral custom and the oracle of Delphi'. 
involving the socialisation of the individual in an intimate and closed community that is distinct from the polis (Burkert 1998, 375), even if it is a situational and a temporary community. At the same time, the festival is clearly Athenian in character.

What makes the Mysteries unique in this context is the individual choice involved (Sourvinou-Inwood 1997, 152). A significant aspect of the relation between individual and collective religious identity is what has been described as a shift in attitudes towards death that took place in the sixth century. According to this interpretation, there was a movement from the acceptance of the notion that death was hateful but not frightening toward a greater concern for the survival of one's memory, which led to a more individualised perception of one's own death. This shift is related to the eschatological promise of a happy afterlife, which has been claimed to be integrated into the religion of the polis (Sourvinou-Inwood 1995, 298-300; 1997, 153-4). This integration, however, is not necessarily thought of as unproblematic by scholars, especially given the various influences on the Mysteries. Orphic influences on the Mysteries can be detected from the end of the fifth century on.$^{53}$ Further on, the Hellenistic era is largely considered to be a period in which the aims of cult and individual religiosity became increasingly soteriological, since it was now easier to choose which cults one wished to follow (Pakkanen 1996, 109-21). It should, however, be pointed out that the eschatological aspect of the Mysteries is much earlier; there is no real contradiction in accepting both an eschatological belief and a promotion of the Mysteries by Athens at the same time, that is at the beginning of the sixth century (Clinton 1994). Eleusinian eschatology has also generated a soteriological discourse in modern times but this is a mere anachronism (Sfameni Gasparro 2013, 148-9). The general trends mentioned do not prove a parallel, soteriological development of the Mysteries. ${ }^{54}$

53 The Mysteries and orphism were still treated as somehow related to one another as late as Paus. 1.37.4, who avoids giving the reason for prohibiting beans in the Mysteries but states that it is well known from the Orphica. For Orpheus as founder of the Eleusinian Mysteries, see Graf 1974, 26-34 and Bremmer 2010, 27-9; for Demeter and the Eleusinian eschatology in the orphic epic, Richardson 1974, 77-86; Graf 1974, 139-50; Bremmer 2002, 23, for their common picture of the afterlife, and Graf 2011, 61, for details in Plato's eschatology referring either to Eleusis or to Bacchic mysteries. Albinus 2000, 162-4, points to the differences between the Eleusinian and orphic genealogies of those playing a part in Demeter's story. He compares the fate of the olbioi in the underworld to the orphic immortality of the soul, drawing the line between orphism and the Mysteries. See also Graf 1974, 81-2.

54 As Larson 2016, 252, points out regarding eschatology, even though we can detect a 'moralisation' during the Classical period, it is best to avoid notions of chronological development from one prevailing form of belief to the next. 
Individualisation through the Mysteries implies obtaining knowledge of a commonly shared secret, the keeping of which was everyone's personal duty. This sharing would create coherence among the initiates even though they never formed any kind of unified religious association, even in times when such associations flourished. While there is no single community of Eleusinian initiates, there would have been several groups spread across the Greek speaking world. There would have been as many distinct groups as there were places of origin for the participants and each group would be as large as the number of mustai coming from that particular single place, presumably travelling together from their homes to Athens during the truce. These groups formed a network around initiation and the goddesses' favours. Mustai did not, however, share a life-style comparable to that of the orphics (Pakkanen 1996, 72). Other than the status of initiate, we have no evidence as to how or whether the participants internalised the whole experience..$^{55}$ The poets and philosophers of the ancient world allude to certain moral values of the initiates while rewards and punishments are a recurrent topic of Eleusinian eschatology. The purity required by the prorrhêsis, as formulated by the chorus of Aristophanes (Ran. 354-7), also shows concern for the soul. This is one further exception to the trend of the increasing internalisation of purity as occurring only in later antiquity. ${ }^{56}$ Speculation on ethics or pragmatic matters regarding the happy afterlife of the initiates is entirely depending on the sources. ${ }^{57}$ While personal ethics are important - even though not consistently, the collective dimension of the festival is still prominent.

Regarding the theoretical frame of individualisation, self-consciousness of the divine favour and the knowledge conveyed by the Mysteries is the basis for the self-categorisation as mustai. This is a valued status that necessitated an emotional involvement and a sense of interdependence between the initiates, at least during the festival. ${ }^{58}$ Indeed, if not for poetic allusions to the flowery underworld and civic occasions such as trials during which only initiates might gather to hear cases related to Eleusinian matters, the social ramifications of the initiate's

55 Vernant 1989, 220, considers the initiate as gaining an internal modification through his familiarity with the two goddesses, even though this entails no socially visible change.

56 See Bremmer 2014, 4. As Petrovic and Petrovic 2016, 11, notice, purity includes a moral dimension.

57 Graf 1974, 140, for the speculative dimension in the orphic epic and in connection with the Eleusinian Mysteries.

58 Rüpke 2015, 10; Rüpke 2016, 5, lists evaluation of membership by individuals, the importance ascribed to this particular membership, the emotional involvement, and the sense of interdependence as aspects defining a group self-categorisation. 
status are entirely obscure. What remains are the narratives about the values, characteristics and history of the group (Rüpke 2016, 5) but these are known for the mustai in only a fragmentary and frustrating way. There is, on the one hand, a 'common knowledge' about what the Mysteries can do for the initiate. On the other hand, there is the specialised knowledge acquired by the initiates during the ritual, through direct transmission and via the preparation that took place over the length of the festival. The broad body of initiates - including politicians and eminent citizens to ordinary individuals, foreigners, slaves, and cult and civic officials - displays a significant diversity regarding their social and certainly religious identity. They cannot be considered as a whole wherein the identity shaped by the quality of mustês is always predominant or, indeed, even religiously motivated in all cases. Individual and/or collective identity is in each case foregrounded depending on the participant's social background and the occasion that motivates his/her participation in the ritual. Both as individuals and as a group, initiates follow a tradition which is thought of as long established by the goddess and guarded by her officials. The initiation process is entirely thoroughly regulated and determined by traditional norms, even though single individuals, for the most part officials, may have, at times, influenced or changed them (Patera 2011). The discourse concerning the Mysteries that was shaped by both Eleusinian officials and the Athenian city implies an ideology of the olbioi, putting the initiates and their fate at the centre.

These multiple parameters limit individual initiative within the regulated ritual frame of the Mysteries. Its norms and practices are meticulously codified by institutional bodies, along with the officials chosen from the two official families discussed above. As a whole, the city has religious authority over the matters concerning the Mysteries. Even in this highly institutionalised frame, the focus on the individual experience of the initiates and the eschatological promises do not lose their gravity. While the Mysteries address the individual, differing in this approach from the polis religion model, there is little beyond personal choice that points to religious individualisation. Initiands tend, rather, to follow an individuation process, defined as a 'gradual full integration into society and the development of self-reflection and of a notion of individual identity' (Rüpke 2013, 7). The more prominent initiates mostly seek a type of distinctiveness, which is to say a form of competitive individuality. Some among them are honoured for their exemplary lives, as was Themistocles of Hagnous in 20/19 (IEleusis 300.31-63; Plut. Mor. 843c), but none is clearly representative of a model to follow. There remains the fact that the rituals focus on the participants who seek olbos and a happy fate, rather than on the gods, as is the case with other civic rituals (Bernabé 2016, 28). Seeing the Mysteries gives the individual a new status within the large and somewhat loose community of initiates. This status might prove at times significant in 
civic life. Beyond specific social occasions, however, the identity of the initiates rather fades throughout their lifetime into other social groupings to which each initiate belongs. At the same time, sweet hopes might accompany them until such a time as they meet their fate in the underworld. Separating the dead initiates from the shadows in Hades in the epics, this individual fate resumes their shared experience as initiates on earth, only this time they are clearly distinct from all the uninitiated.

\section{References}

Albinus, Lars. 2000. The House of Hades: Studies in ancient Greek eschatology. Aarhus: Aarhus University Press.

Bernabé, Alberto. 2012. 'A Brave Netherworld: the orphic Hades as utopia.' In Demeter, Isis, Vesta, and Cybele: Studies in Greek and Roman religion in honour of Giulia Sfameni Gasparro, eds. A. Mastrocinque, C. Giuffrè Scibona, Stuttgart: Steiner Verlag. 11-23.

Bernabé, Alberto. 2016. 'Aristotle and the Mysteries.' In Greek Philosophy and Mystery Cults, eds. M. J. Martín-Velasco, M. J. García Blanco, Newcastle upon Tyne: Cambridge Scholars Publishing. 27-42.

Bowie, Angus M. 1993. Aristophanes: Myth, ritual and comedy. Cambridge: Cambridge University Press.

Bremmer, Jan N. 1983. The Early Greek Concept of the Soul. Princeton: Princeton University Press.

Bremmer, Jan N. 1994. Greek Religion. Oxford: Oxford University Press.

Bremmer, Jan N. 1995. 'Religious Secrets and Secrecy in Classical Greece.' In Secrecy and Concealment: Studies in the history of Mediterranean and Near Eastern religions, eds. H. G. Kippenberg, G. S. Stroumsa, Numen Suppl. 65. 61-78.

Bremmer, Jan N. 2002. The Rise and Fall of the Afterlife. London: Routledge.

Bremmer, Jan N. 2010. 'Manteis, Magic, Mysteries and Mythography: Messy margins of polis religion?', Kernos 23. 13-35.

Bremmer, Jan N. 2014. Initiation into the Mysteries of the Ancient World. Berlin: de Gruyter. Burkert, Walter. $1985\left(1977^{1}\right)$. Greek Religion. Cambridge Mass.: Harvard University Press. Burkert, Walter. 1987. Ancient Mystery Cults. Cambridge Mass.: Harvard University Press.

Burkert, Walter. 1995. 'Greek Poleis and Civic Cults: Some further thoughts.' In Studies in the ancient Greek polis, eds. M. H. Hansen, K. Raaflaub, Stuttgart: Steiner Verlag. 201-10.

Burkert, Walter. 1998. 'Le secret public et les mystères dits privés.' In Public et privé en Grèce ancienne: Lieux, objets, pratiques. Actes du colloque international organisé à Paris les 15-17 mars 1995, eds. P. Schmitt-Pantel, F. de Polignac, Ktema 23. 375-81.

Cataldi, Silvio. 1981. 'Un regolamento ateniese sui misteri Eleusini e l'ideologia panellenica di Cimone.' In Studi sui rapporti interstatali nel mondo antico, ed. G. Nenci, Pisa: Scuola Normale Superiore. 73-146.

Clinton, Kevin. 1974. The Sacred Officials of the Eleusinian Mysteries. TAPhS 64.3. Philadelphia.

Clinton, Kevin. 1980. 'A Law in the City Eleusinion concerning the Mysteries', Hesperia 49. 258-88. 
Clinton, Kevin. 1989. 'Hadrian's Contribution to the Renaissance of Eleusis.' In The Greek Renaissance in the Roman Empire: Papers from the tenth British Museum classical colloquium, eds. S. Walker, A. Cameron, BICS Suppl. 55, London. 56-68.

Clinton, Kevin. 1989b. 'The Eleusinian Mysteries: Roman initiates and benefactors, second century B.C. to A.D. 267', Aufstieg und Niedergang der römischen Welt II.18.2. 1499-539.

Clinton, Kevin. 1994. 'The Eleusinian Mysteries and Panhellenism in Democratic Athens.' In The Archaeology of Athens and Attica under the Democracy: Proceedings of an international conference celebrating 2500 years since the birth of democracy in Greece, held at the American School of Classical Studies at Athens, December 4-6, 1992, eds. W. D. E. Coulson et al. Oxbow monograph 37. Oxford. 161-72.

Clinton, Kevin. 1997. 'Eleusis and the Romans: Late Republic to Marcus Aurelius.' In The Romanization of Athens: Proceedings of an international conference held at Lincoln, Nebraska (April 1996), eds. M. C. Hoff, S. I. Rotroff. Oxbow monograph 94. 161-81.

Clinton, Kevin. 1999. 'Eleusis from Augustus to the Antonines: Progress and problems.' In XI Congresso internazionale di epigrafia greca e latina, Roma 18-24 settembre 1997. Atti II, Rome: Quasar. 93-102.

Clinton, Kevin. 2003. 'Stages of Initiation in the Eleusinian and Samothracian Mysteries.' In Greek Mysteries: The archaeology and ritual of ancient Greek secret cults, ed. M. B. Cosmopoulos, London: Routledge. 50-78.

Clinton, Kevin. 2005. Eleusis. The Inscriptions on stone: Documents of the sanctuary of the two goddesses and public documents of the deme, I A. Text. Athens.

Clinton, Kevin. 2008. Eleusis. The Inscriptions on stone: Documents of the sanctuary of the two goddesses and public documents of the deme, II. Commentary. Athens.

Clinton, Kevin. 2008b. 'Preliminary Initiation in the Eleusinian Mysteries.' In Mikros hieromnêmôn. Meletes eis mnêmên Michael H. Jameson, eds. A. Matthaiou, I. Polinskaya, Athens. 25-34.

de Heer, Cornelis. 1969. Makar, eudaimôn, olbios, eutuchês: A study of the semantic field denoting happiness in ancient Greek to the end of the 5th century B.C. Amsterdam: Hakkert.

de Polignac, François. 2009. 'Sanctuaries and Festivals.' In A Companion to Archaic Greece, eds. K. A. Raaflaub, H. van Wees, Malden: Blackwell. 427-43.

Dickie, Matthew K. 2004. 'Priestly Proclamations and Sacred Laws', Classical Quarterly 54. 579-91.

Dowden, Ken. 1980. 'Grades in the Eleusinian Mysteries', Revue de l'Histoire des Religions 197. 409-27.

Eidinow, Esther. 2011. 'Networks and Narratives: A model for ancient Greek religion', Kernos 24. 9-38.

Fabiano, Doralice. 2010. "'Ho fugito il male, ho trovato il meglio": le punizioni dei non iniziati nell'aldilà greco', Archiv für Religionsgeschichte 12. 149-65.

Foley, Helene P. (ed.). 1994. The Homeric Hymn to Demeter: Translation, commentary and interpretive essays. Princeton: Princeton University Press.

Gagné, Renaud. 2009. 'Mystery Inquisitors: Performance, authority, and sacrilege at Eleusis', Classical Antiquity 48. 211-47.

Graf, Fritz. 1974. Eleusis und die orphische Dichtung Athens in vorhellenistischer Zeit. Berlin: de Gruyter.

Graf, Fritz. 1996. 'Pompai in Greece: Some considerations about space and ritual in the Greek polis.' In The Role of Religion in the Early Greek Polis: Proceedings of the third 
international seminar on ancient Greek cult, ed. R. Hägg, Stockholm: Svenska Institutet i Athen. 55-65.

Graf, Fritz. 2003. 'Initiation: A concept with a troubled history.' In Initiation in ancient Greek ritual and narratives: New critical perspectives, eds. D. B. Dodd, C. A. Faraone, London: Routledge. 3-24.

Graf, Fritz. 2011. 'Text and Ritual: The Corpus Eschatologicum of the Orphics.' In The 'Orphic' Gold Tablets and Greek Religion: Further along the path, ed. R. G. Edmonds III, Cambridge: Cambridge University Press. 53-67.

Kindt, Julia. 2009. 'Polis Religion: A critical appreciation', Kernos 22. 9-34.

Kindt, Julia. 2015. 'Personal Religion: a productive category for the study of ancient Greek religion?', Journal of Hellenic Studies 135. 35-50.

Kuhn, Annika. 2006. 'Ritual Change during the Reign of Demetrius Poliorcetes.' In Ritual and Communication in the Graeco-Roman World, ed. E. Stavrianopoulou, Kernos Suppl. 16. 265-81.

Larson, Jennifer. 2016. Understanding Greek Religion: A cognitive approach. London: Routledge.

Lévêque, Pierre. 1982. 'Olbios et la félicité des initiés.' In Rayonnement grec. Hommages à Charles Delvoye, eds. L. Hadermann-Misguich, G. Rapsaet, Brussels: Éditions de l'Université de Bruxelles. 113-26.

Lippolis, Enzo. 2013. 'Eleusis. Sanctuary of the Empire.' In Roman Power and Greek Sanctuaries: Forms of interaction and communication, ed. M. Galli, Athens: Scuola archeologica italiana di Atene. 245-64.

Otto, Bernd-Christian. 2017. 'Magic and Religious Individualization: On the construction and deconstruction of analytical categories in the study of religion', Historia Religionum 9. 29-52.

Pakkanen, Petra. 1996. Interpreting Early Hellenistic Religion: A study based on the mystery cult of Demeter and the cult of Isis. Helsinki: Finnish Institute at Athens.

Parker, Robert. 2005. Polytheism and Society at Athens. Oxford: Oxford University Press.

Parker, Robert. 2015. 'Public and Private.' In A Companion to the Archaeology of Religion in the Ancient World, eds. R. Raja, J. Rüpke, Malden: Blackwell. 71-80.

Patera, Ioanna. 2011. 'Changes and Arrangements in a traditional Cult: The case of the Eleusinian rituals.' In Ritual Dynamics in the Ancient Mediterranean: Agency, emotion, gender, representation, ed. A. Chaniotis, Stuttgart: Steiner Verlag. 119-37.

Petridou, Georgia. 2013. “'Blessed is he, who has seen”: The power of ritual viewing and ritual framing in Eleusis', Helios 40. 309-41.

Petridou, Georgia. 2015. Divine Epiphany in Greek Literature and Culture. Oxford: Oxford University Press.

Petrovic, Andrej; Petrovic, Ivana. 2016. Inner Purity and Pollution in Greek Religion. I: Early Greek religion. Oxford: Oxford University Press.

Richardson, Nicholas J. 1974. The Homeric Hymn to Demeter. Oxford: Oxford University Press.

Riedweg, Christoph. 1987. Mysterienterminologie bei Platon, Philon, und Klemens von Alexandrien. Berlin: de Gruyter.

Rudhardt, Jean. $1992\left(1958^{1}\right)$. Notions fondamentales de la pensée religieuse et actes constitutifs du culte dans la Grèce classique. Paris: Picard.

Rüpke, Jörg. 2011. 'Lived Ancient Religion: Questioning “cults” and “polis religion”, Mythos 5. 191-204. 
Rüpke, Jörg. 2013. 'Individualization and Individuation as Concepts for Historical Research.' In The Individual in the Religions of the Ancient Mediterranean, ed. J. Rüpke, Oxford: Oxford University Press. 3-38.

Rüpke, Jörg. 2015. 'Religious Agency, Identity, and Communication: Reflections on history and theory of religion', Religion. 1-23.

Rüpke, Jörg. 2016. 'Creating Groups and Individuals in Textual Practices', Religion in the Roman Empire 2.1. 3-9.

Scafuro, Adele C. 2010. 'Conservative Trends in Athenian Law: IE 138, a law concerning the Mysteries.' In Symposion 2009, ed. G. Thür, Vienna. 23-46.

Sfameni Gasparro, Giulia. 2013. 'Après Lux perpetua de Franz Cumont: quelle eschatologie dans les 'cultes orientaux' à mystères?' In Panthée: Religious transformations in the Graeco-Roman empire, eds. L. Bricault, C. Bonnet, Leyde: Brill. 145-67.

Simms, Robert M. 1990. 'Myesis, Telete, and Mysteria', Greek, Roman, and Byzantine Studies 31. 183-95.

Sokolowski, Franciszek. 1959. 'On the Rules Regulating the Celebration of the Eleusinian Mysteries', Harvard Theological Review 52.1-7.

Sourvinou-Inwood, Christiane. 1988. 'Further Aspects of Polis Religion', Annali dell'Istituto universitario orientale di Napoli. Dipartimento di studi del mondo classico e del Mediterraneo antico. Sezione di archeologia e storia antica 10. 259-74.

Sourvinou-Inwood, Christiane. 1990. 'What is Polis Religion?' In The Greek City from Homer to Alexander, eds. O. Murray, S. Price, Oxford: Clarendon Press. 295-322.

Sourvinou-Inwood, Christiane. 1995. 'Reading' Greek Death: To the end of the classical period. Oxford: Clarendon Press.

Sourvinou-Inwood, Christiane. 1997. 'Reconstructing Change: Ideology and the Eleusinian Mysteries.' In Inventing Ancient Culture: Historicism, periodization and the ancient world, eds. M. Golden, P. Toohey, London: Routledge. 132-64.

Sourvinou-Inwood, Christiane. 2003. 'Festival and Mysteries: Aspects of the Eleusinian cult.' In Greek Mysteries: The archaeology and ritual of ancient Greek secret cults, ed. M. B. Cosmopoulos, London: Routledge. 25-49.

Stehle, Eva. 2007. 'Thesmophoria and Eleusinian Mysteries: The fascination of women's secret ritual.' In Finding Persephone: Women's rituals in the ancient Mediterranean, eds. M. Parca, A. Tzanetou, Bloomington: Indiana University Press. 165-85.

Vernant, Jean-Pierre. 1989 (1987). 'L'individu dans la cité.' In L'individu, la mort, l'amour. Paris: Gallimard. 211-32.

Waldner, Katharina. 2013. 'Dimensions of Individuality in Ancient Mystery Cults: Religious practice and philosophical discourse.' In The Individual in the Religions of the Ancient Mediterranean, ed. J. Rüpke, Oxford: Oxford University Press. 215-42. 